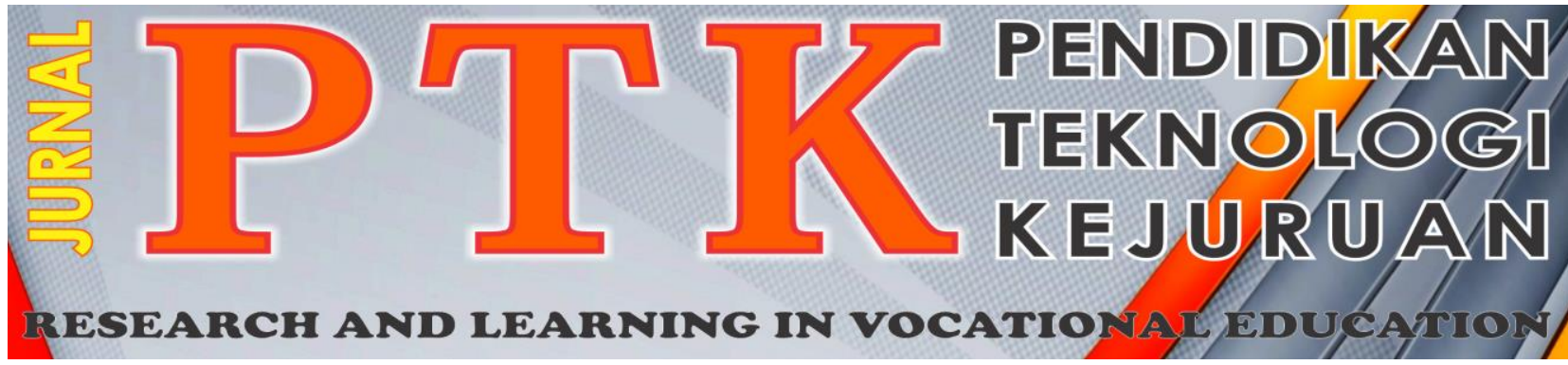

Vol. 1, No. 2 Mei 2018

P-ISSN: 2621-3273

E-ISSN: 2621-1548

\title{
MEWUJUDKAN TUJUAN PENDIRIAN AKADEMI KOMUNITAS MELALUI PENERAPAN MODEL PROJECT BASED LEARNING
}

\author{
Rahmat Azis Nabawi ${ }^{1}$, Nizwardi Jalinus ${ }^{2}$ dan Syahril ${ }^{3^{*}}$ \\ Universitas Negeri Padang \\ *Corresponding author, e-mail: syahril@ft.unp.ac.id
}

\begin{abstract}
Abstrak - Akademi komunitas merupakan bentuk Pendidikan vokasional baru yang ada di Indonesia. Basis pendirian dari Akademi komunitas ini adalah keunggulan lokal atau memenuhi kebutuhan khusus, hal ini bertujuan untuk mengembangkan potensi yang ada didaerah. Untuk mewujudkan tujuan dari pendirian Akademi Komunitas ini, maka perlunya suatu inovasi pada kegiatan pembelajaran yaitu dengan memilih model pembelajaran yang dapat mewujudkan tujuan dari pendirian Akademi Komunitas tersebut. Artikel ini bertujuan untuk mendiskripsikan pembelajaran Praktek Las di Akademi Komunitas dengan penerapan model project based learning dalam mewujudkan tujuan pendiriannya. Penelitian ini merupakan penelitian deskriptif. Data penelitian diperoleh dari observasi, wawancara dan dokumentasi. Dari penerapan model project based learning pada mata kuliah praktek las yang telah dilakukan mahasiswa mampu mengidentifikasi potensi, tantangan atau masalah yang ada didaerah sekitaran Akademi Komunitas. Hasil indetifikasi dan diskusi tentang potensi daerah yang dilakukan oleh mahasiswa adalah pada bidang pertanian dan masalahnya alat pertanian yang dimiliki oleh petani masih konvesional. Berdasarkan hal ini mahasiswa membuat tugas proyek berupa alat pertanian sederhana. Produk hasil tugas proyek mahasiswa ini berpotensi untuk mengembangkan potensi daerah dan memecahkan masalah yang berkembang dimasyarakat.
\end{abstract}

Kata kunci : Akademi Komunitas, Pendidikan Vokasional, Project Based Learning, Potensi Daerah

Abstract-community collage as a new the vocational education in Indonesia. The founding base of this community college is local excellence or meeting special needs, it aims to develop the potential that exists in the region. To realize the purpose of the establishment of this community college, the need for an innovation in learning activities that is by choosing a model of learning that can realize the purpose of the establishment of the community college. This article aim to describe the learning of Las Practice in Community college with the implementation of project based learning model in realizing the purpose of its establishment. This study is a descriptive research. Research data obtained from observation, interview and documentation. From the implementation of project based learning model in the welding practice courses that have been done, the students are able to identify the potential, challenges or problems that exist in the area surrounding the community college. The results of identification and discussion of the potential of developed areas is in agriculture and the problem of farming tools owned by farmers is still conventional. Based on this the students make the project task in the form of simple farming tools. The product of this project's project work has the potential to develop the potential of the region and solve the problems that develop in the community.

Keywords: Community Collage, Vocational education, Project based learning, Potential Areas

Copyright (c) 2018 JPTK. All rights reserved

\section{Pendahuluan}

Indonesia memiliki bentuk pendidikan vokasional baru yaitu Akademi Komunitas, yang pendiriannya diutamakan berada di Kabupaten/Kota bukan pada
Ibu Kota Provinsi. Akademi Komunitas ini mulai berdiri di Indonesia sejak tahun 2012, pada tahun tersebut telah berdiri sebanyak 20 Akademi Komunitas di 20 Kabupaten/Kota dan terus 
bertambah jumlahnya, karena banyak Kabupaten/Kota yang terus mengajukan kepada Kementrian Riset dan Teknologi dan Pendidikan Tinggi Indonesia untuk menyelenggarakan Pendidikan Tinggi dalam bentuk Akademi Komunitas tersebut. Akademi Komunitas merupakan perguruan tinggi yang menyelenggarakan pendidikan vokasi setingkat diploma satu dan/atau diploma dua dalam satu atau beberapa cabang ilmu pengetahuan dan/atau teknologi tertentu yang berbasis keunggulan lokal atau untuk memenuhi kebutuhan khusus [1].

Potensi daerah atau kearifan lokal merupakan basis dari pendirian Akademi Komunitas. Pengembangan potensi daerah atau kerarifan lokal oleh Akademi Komunitas merupakan suatu strategi yang diharapkan mumpuni dalam mengembangkan potensi Indonesia secara menyeluruh sampai kedaerah. Selama ini perguruan tinggi yang umumnya berdomisili di Ibu Kota Provinsi belum optimal dalam menangkap atau menyelesaikan permasalahan atau tantangan yang berkembang dimasyarakat yang ada di daerah. Akademi Komunitas yang berada dekat dengan masyarakat daerah tentu akan menjadi kloter awal dalam menerima, menganalisis atau menggali masalah yang berkembang dimasyarakat daerah dan memecahkan masalah tersebut. Pendirian Akademi Komunitas bertujuan untuk mempercepat laju pembangunan Indonesia dengan memeratakan dan memudahkan akses pendidikan tinggi pada masyarakat yang ada didaerah [2].

Potensi daerah sebagai basis pendirian akademi komunitas merupakan perwujudan dari harapan dalam menjawab persoalan dan tantangan yang berkembang atau muncul di daerah. Terwujudnya harapan ini dapat diraih dengan menerapkan model pembelajaran yang dapat mengintegrasikan pemecahan masalah dan pengembangan potensi daerah pada kegiatan pembelajaran. Kegiatan pembelajaran dengan penerapan model pembelajaran yang dapat mengakomodir masalah yang ada dimasyarakat untuk dapat dipecahkan atau potensi daerah dapat dikembangkan tentu dapat mengatasi masalah yang terjadi dan dapat terjawabnya dasar dari pendirian akademi komunitas yaitu mengembangkan potensi lokal dan menjawab tantangan atau permasalahan yang berkembang dimasayarakat yang selaras dengan keilmuan yang diselenggarakan di Akademi Komunitas. Model pembelajaran yang menjadikan masalah dari dunia nyata sebagai dasar dari pelaksanaan tugas proyek Mahasiswa dalam pembelajaran adalah model project based learning (PjBL).

PjBl adalah pembelajaran yang memberikan kesempatan kepada Mahasiswa untuk melakukan proses pencarian pada persoalan dan permasalahan dari dunia nyata yang relevan dengan pembelajaran yang dipelajari [3]. Kerja proyek pada model PjBL bahwa kerja proyek memuat tugas-tugas yang kompleks berdasarkan kepada pertanyaan dan permasalahan dari dunia nyata yang menantang, menuntut peserta didik untuk merancang, memecahkan masalah, membuat keputusan, melakukan investigasi, dan memberikan kesempatan kepada peserta didik untuk bekerja secara mandiri maupun berkelompok [4]. Tugas proyek Mahasiswa dalam PjBL berangkat dari masalah yang ditemukan dari dunia nyata [5]. Penerapan model PjBL membuat Mahasiswa percaya diri untuk dapat mengerjakan proyek dari kebutuhan atau tantangan yang berkembang dimasyarakat yang sesuai dengan bidang keilmuannya [6].

Artikel ini bertujuan untuk mendiskripsikan kegiatan pembelajaran pada akademi komunitas dengan penerapan model PjBL dalam mewujudkan tujuan dari penyelenggaran Akademi Komunitas di daerah dalam mengembangkan potensi, menjawab tantangan atau memecahkan permasalahan yang berkembang dimasyarakat daerah. Deskripsi dari kegitan pembelajaran dengan penerapan model $\mathrm{PjBL}$ pada Mata Kuliah Praktek Las II ini merupakan hasil dari penelitian [7] yang telah dilakukan. Hal ini dikarenakan dari hasil penelitian [7] tentang penerapan model PjBL pada pembelajaran Praktek Las dalam Program Studi Teknik Mesin di Akademi Komunitas Negeri Tanah Datar (AKNTD) dengan tugas proyek Mahasiswa diangkat dari potensi dan masalah dari daerah sekitaran Akademi Komunitas, menemukan bahwa model PjBL yang diterapkan pada pembelajaran praktek las dapat meningkatkan kemampuan pemecahan masalah dan kompetensi keahlian Mahasiswa, dan tugas proyek yang diangkat dari dunia nyata yang lebih tepat dari masalah yang ada dilingkungan sekitar mereka membuat tingginya motivasi Mahasiswa tersebut untuk belajar dan melaksanakan tugas proyek.

\section{RASIONAL PENDIRIAN AKADEMI KOMUNITAS}

Rasional pendirian Akademi Komunitas adalah suatu upaya untuk meningkatkan lulusan pendidikan vokasional yang berorientasi kepada dunia kerja. Peningkatan kualitas sumber daya manusia melalui pendidikan tinggi dengan meningkatkan presentase lulusan pendidikan vokasinal yang siap pakai, maka akan memberi konstribusi dengan menambah komposisi tenaga kerja profesional yang berkualitas. Posisi strategis Akademi Komunitas adalah memanfaatkan peluang demografis yaitu tinggi jumlah penduduk yang berusia produktif yang dapat berpotensi menjadi faktor pemicu percepatan 
pembangunan dan kesejahteraan ekonomi di seluruh daerah kabupaten/kota yang ada di Indonesia.

Sesuai dengan karakteristik, jenis dan tujuannya Akademi Komunitas yang mengemban amanah untuk menghasilkan lulusan yang mampu mengembangkan potensi daerah, menjawab tantangan dan memecahkan masalah yang berkembang dimasyarakat, tentu nantinya lulusan akan dapat menciptakan usaha-usaha baru didaerah. Hadirnya usaha baru dari lulusan Akademi Komunitas dengan mengembangkan potensi daerah tentu akan mempercepat laju pertumbuhan ekonomi. Pemerataan ekonomi menjadi suatu keniscayaan dengan hadir Akademi Komunitas di daerah ini.

Program studi yang diselenggarakan di Akademi Komunitas harus disesuaikan dengan potensi yang ada didaerah dan juga diharapkan dapat bekerja sama dengan industri lokal yang ada didaerah tersebut, sehingga lulusan yang dihasilkan sesuai dengan kebutuhan dan dapat terserap industri lokal tersebut. Sistem pendidikan akademi komunitas harus tanggap dalam menampung setiap aspirasi yang muncul, hal ini akan mewujudkan sinergi saling membangun antara pemerintah daerah, masyarakat dan industri lokal dengan Akademi Komunitas dalam memajukan daerah tersebut.

Penyelenggaraan Akademi Komunitas di daerah juga bertujuan untuk memperluas akses dan pemerataan pendidikan tinggi. Setiap lulusan sekolah menengah dari keluarga ekonomi rendah, yang tidak mampu melanjutkan pendidikan pada perguruan tinggi yang umumya ada di Ibu Kota Provinsi dapat mengecap pendidikan tinggi didaerahnya sendiri. Kondisi ini akan membantu masyarakat ekonomi rendah untuk memperoleh pendidikan yang berkualitas dan menambah angka lulusan pendidikan vokasional yang profesional dibidangnya yang memiliki keunggulan yaitu mempunyai keahlian untuk mampu mengembangkan potensi yang ada didaerahnya.

\section{Model Project BASED LEARNING}

Model PjBL adalah model belajar yang sistematis, yang melibatkan Mahasiswa dalam belajar pengetahuan dan keterampilan melalui proses pencarian/penggalian yang panjang dan terstruktur terhadap pertanyaan yang otentik dan komplek serta tugas dan produk yang dirancang dengan sangat hati-hati [8]. Pembelajaran berbasis proyek merupakan pembelajaran yang bersifat membangun dan metode dasar penemuan, yang kedua tergantung kepada proses pencarian dan kemampuan Mahasiswa untuk menyusun solusi berdasarkan pandangan masing-masing dan cara berfikir. PjBL adalah suatu proses yang cermat, sistematis yang menggunakan metodologi yang berbeda untuk menghasilkan pemikiran terbaik Mahasiswa, tetapi juga menentapkan parameter dan tujuan untuk keterampilan dan pengetahuan yang akan diperoleh oleh Mahasiswa [9]. Pembelajaran berbasis proyek mengarahkan Mahasiswa pada merancang, merencanakan, dan hasil dari proyek berupa produk yang dipublikasi atau dipresentasi [10]. Dari apa yang dijelaskan oleh ahli tersebut dapat dipahami bahwa model PjBL adalah pembelajaran yang sistematis yang mana penerapannya dalam pembelajaran sesuai dengan pola yang sudah ditentukan dan pola dalam pembelajaran berbasis proyek diadopsi dari kerja nyata dunia industri atau usaha.

PjBL dapat dikatakan sebagai konsep pendidikan berbasis tugas proyek dalam memproduksi suatu produk yang diangkat dari dunia nyata dan dapat diterapkan dalam pendidikan vokasional. Prinsip dari PjBL ini sangat cocok dengan Akademi Komunitas, dimana Mahasiswa bukan hanya disiapkan untuk dunia industri tetapi juga bisa mengembangkan potensi daerah sehingga lulusan dapat menjadi wirausahawan nantinya yang mampu mengoptimalkan dan memanfaatkan potensi daerah mereka.

Implementasi model $\mathrm{PjBL}$ ialah pada keikutsertaan pembelajar dalam memahami realitas kehidupan dari yang konkret sampai ke yang abstrak [11]. Untuk penerapan model $\mathrm{PjBL}$ pada kegiatan pembelajaran maka diperlukan sintak dari model sebagai bahan referensi bagi Dosen untuk menyusun rencana pembelajaran semester (RPS) dan pelaksanaan kegiatan pembelajaran. [12] mengembangkan sintak model $\mathrm{PjBL}$ yang terdiri dari tujuh tahapan pembelajaran yang disusun secara sistematis, mempunyai tujuan kemampuan akhir yang diharapkan dari masing-masing sintak dan saling terkait antara masing-masing sintak sehingga menciptakan pembelajaran yang efektif dalam mengembangkan kompetensi Mahasiswa. 


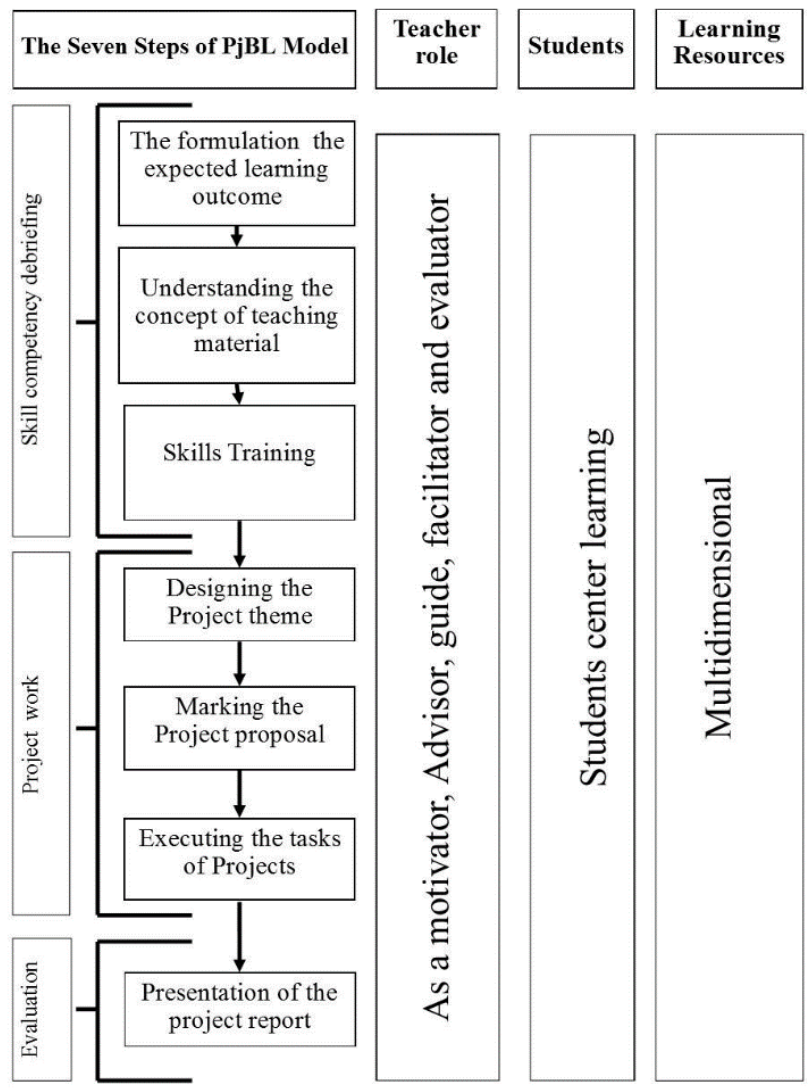

Gambar 1. Sintak Model PjBL dengan tujuh langkah Pembelajaran [12]

\section{METOde PENELITIAN}

Metode penelitian yang digunakan adalah metode penelitian deskriptif. Penelitian ini bukan untuk menguji sebuah hipotesis tetapi mendeskripsikan bentuk dari kegiatan pembelajaran dengan penerapan model PjBL dalam menciptakan pembelajaran yang dapat menjawab dasar dari pendirian Akademi Komunitas yaitu berbasis potensi daerah, keunggulan lokal, menjawab tantangan yang berkembang dimasyarakat atau masalah dari dunia nyata disekitaran daerah Akademi Komunitas. Subjek penelitian ini adalah Dosen dan Mahasiswa pada kegiatan pembelajaran mata kuliah Praktek Las II pada Program Studi Teknik mesin AKNTD, Program Studi Domisili Politeknik Negeri Padang. Pengumpulan data dilakukan dengan wawancara, observasi dan dokumentasi.

\section{Deskripsi Penerapan Model PJBL}

Deskripsi dari kegiatan pembelajaran pada mata kuliah Praktek Las II dengan penerapan model PjBL dijabarkan sebagai berikut:

\section{A. Persiapan Pelaksanaan Pembelajaran}

Pada kegiatan pelaksanaan pembelajaran ini Dosen menyiapkan dan mempelajari beberapa hal terkait dengan kegiatan pembelajaran yang akan dilaksanakan. Hal-hal yang perlu dipersiapkan oleh Dosen sebelum pelaksanaan pembelajaran dengan penerapan model $\mathrm{PjBL}$ adalah:

1. Visi dan misi, capaian pembelajaran lulusan, dan profil lulusan yang tertuang dalam kurikulum Program Studi

2. Analisis karakeristik dan kompetensi awal Mahasiswa yang diajarkan. Hal ini dapat diketahui dari nilai Mahasiswa pada mata kuliah sebelumnya dan untuk karakter Mahasiswa dapat didiskusikan dengan Dosen sejawat yang pernah mengajar Mahasiswa yang akan diajarkan

3. Sarana prasarana pembelajaran, seperti media pembelajaran, peralatan alat dan mesin pratikum dan bahan pratikum Mahasiswa

4. Analisis potensi, tantangan dan masalah yang berkembang didaerah sekitaran Akademi Komunitas.

5. Penyusunan atau revisi Rencana Pembelajaran Semester (RPS) dan bahan ajar yang sesuai dengan model pembelajaran yang akan diterapkan.

Hal-hal yang tersebut diatas harus dilaksanakan oleh Dosen dalam persiapan palaksanaan pembelajaran, agar penerapan model pembelajaran dapat teralisasi dengan baik. RPS yang telah disusun menjadi panduan bagi Dosen dan Mahasiswa untuk pelaksanaan kegiatan pembelajaran. Bahan ajar dapat menjadi salah satu sumber belajar bagi Mahasiswa.

Program Studi Teknik Mesin AKNTD memiliki kefokusan kelimuan pada bidang fabrikasi dan pengelasan logam. Mata kuliah Praktek las II mengajarkan dengan memberikan pengetahuan dan pelatihan keterampilan kepada Mahasiswa untuk memiliki kompetensi teknik pengelasan menggunakan mesin shielded Metal Arc Welding (SMAW), Metal Inert Gas (MIG), Oxygen Acetylene Welding (OAW) dan Tungsten Inert Gas (TIG). Alokasi waktu pembelajaran adalah 18 pertemuan dengan satu pertemuan enam jam pembelajaran dan satu jam pembelajaran dengan durasi waktu 50 menit.

Capaian pembelajaran dari mata kuliah Praktek Las II adalah Mahasiswa dituntut mampu mengaplikasikan proses pengelasan dan posisi pengelasan setara dengan jenjang/level SKKNI level/sertifikat II pada bidang jasa industri pengelasan dan Mahasiswa juga dituntut untuk mampu membuat produk kreatif dari potensi daerah dan bernilai secara ekonomi yang sesuai dengan pekerjaan teknik mesin.

Mahasiswa yang mengambil mata kuliah Praktek las merupakan mahasiswa yang sudah lulus semua mata kuliah pada semester satu, yang terdiri dari mata kuliah Tata Tulis Laporan, matematika, Fisika, 
Teknologi Mekanik I, Komputer \& Internet, Gambar Teknik, Praktek Kerja Bangku dan Pelat, dan Praktek Las 1. Hasil diskusi dengan Dosen telah mengajar mahasiswa yang mengambil mata kuliah Praktek Las II dapat disimpulkan bahwa mahasiswa sudah memiliki pengetahuan dan keterampilan dasar di bidang teknik pengelasan logam, memiliki motivasi yang cukup tinggi untuk belajar, dan ratarata nilai mahasiswa cukup memuaskan. Sarana Pembelajaran terdiri dari satu gedung workshop pengelasan dan media pembelajaran terdiri dari 10 unit mesin las SMAW, dua unit mesin las OAW, lima unit mesin TIG dan dua unit mesin las MIG. Begitu juga dengan ketersediaan bahan praktek yang cukup untuk sebagai bahan praktek mahasiwa untuk pelaksanaan tugas proyek.

Hasil observasi, analisis dan diskusi dengan Dosen AKNTD tentang potensi daerah, tantangan dan masalah yang berkembang dimasyarakat di sekitaran daerah Kabupaten Tanah Datar, dapat disimpulkan bahwa banyak produk kreatif dari potensi daerah yang berkaitan dengan pekerjaan bidang teknik mesin khususnya pada pengelasan logam untuk dapat dibuat atau dikembangkan. Produk kreatif dari potensi daerah yang dapat dibuat terdiri dari alat dan mesin pertanian, mobiler, asesoris motor dan mobil, alat dan mesin untuk usaha kecil dan menengah, teknologi tepat guna dan lain sebagainya.

Dalam penyusunan RPS dan Bahan Ajar hasil analisis kurikulum, analisis sarana prasarana pembelajaran, dan analisis potensi, tantangan dan permasalahan yang terjadi didaerah dapat menjadi referensi. RPS disusun sedemikian rupa dengan mengacu kepada Peraturan Meteri Riset, Teknologi, dan Pendidikan Tinggi Republik Indonesia Nomor 44 Tahun 2015 Tentang Standar Nasional Pendidikan Tinggi dan tambahan kolom untuk sintak dari model PjBL yang akan diterapkan, hasil kajian tersebut diterjemahkan menjadi bentuk tabel sederhana yang mudah dimengerti seperti yang disajikan pada gambar 1 .

\section{RENCANA PEMBELAJARAN SEMESTER}

\begin{tabular}{|c|c|c|c|c|c|c|c|c|c|}
\hline \multicolumn{5}{|c|}{ Program Studi: .................................................. } & \multicolumn{5}{|c|}{ 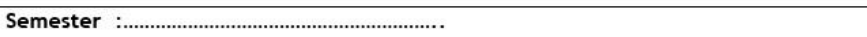 } \\
\hline \multicolumn{5}{|c|}{ Mata kuliah:....................., Kode:..................., SKS:............... } & \multicolumn{5}{|c|}{ 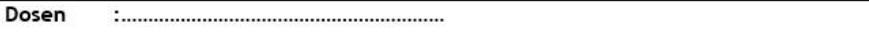 } \\
\hline \multicolumn{2}{|c|}{ Capaian Pembelajaran } & \multicolumn{8}{|c|}{$\begin{array}{l}\text { Berisi capaian pembelajaran yang dari mata kuliah yang akan dicapai setelah pembelajaran selesai dilaksanakan dan merupakan hilirisasi dari capaian } \\
\text { pembelajaran lulusan program studi. }\end{array}$} \\
\hline $\begin{array}{c}\text { Kegiatan } \\
\text { pembelajaran }\end{array}$ & Pert. Ke & $\begin{array}{l}\text { Kemampuan } \\
\text { Akhir yang } \\
\text { diharapkan }\end{array}$ & Bahan kajian & $\begin{array}{c}\text { Metode dan } \\
\text { stategi } \\
\text { Pembelajaran }\end{array}$ & $\begin{array}{l}\text { Bentuk Tugas } \\
\text { Mahasiswa }\end{array}$ & Alokasi Waktu & Evaluasi & $\begin{array}{c}\text { Kriteria, } \\
\text { indikator dan } \\
\text { bobot nilai }\end{array}$ & Referensi \\
\hline $\begin{array}{l}\text { Kegiatan } \\
\text { pembelajaran } \\
\text { digambar dari } \\
\text { sintak Model, } \\
\text { setiap baris } \\
\text { tabel terdapat } \\
\text { satu sintak } \\
\text { Model. }\end{array}$ & \begin{tabular}{|l} 
Direncanakan \\
pada \\
pertemuan \\
keberapa atau \\
satu kegiatan \\
pembelajaran \\
yang istilah \\
dengan sintak \\
atau tahapan \\
pembelajaran \\
dapat terdiri \\
dari beberapa \\
pertemuan.
\end{tabular} & \begin{tabular}{l|l} 
& Berisi tentang \\
yang \\
u & kemampuan \\
n akhir yang \\
n & diharapkan dari \\
hetiap akhir & sep kegiatan \\
h & satu ptu \\
k & pembelajaran \\
n & untuk \\
ri & memenuhi \\
a & capaian \\
pembelajaran.
\end{tabular} & $\begin{array}{l}\text { Bahan kajian } \\
\text { yang ditelaah } \\
\text { untuk } \\
\text { mencapai } \\
\text { kemampuan } \\
\text { yang akhir } \\
\text { akan } \\
\text { diharapkan }\end{array}$ & $\begin{array}{lr}\text { Metode dan } \\
\text { strategi yang } \\
\text { terkadung dalam } \\
\text { model } \\
\text { pembelajaran yang } \\
\text { diterapkan. }\end{array}$ & \begin{tabular}{|l|}
\multicolumn{2}{|l|}{ Pengalaman } \\
belajar yang \\
diwujudkan \\
dalam deskripsi \\
tugas yang harus \\
dikerjakan oleh \\
mahasiswa pada \\
setiap sintak \\
model \\
pembelajaran.
\end{tabular} & $\begin{array}{l}\text { Waktu yang } \\
\text { disediakan untuk } \\
\text { mencapai } \\
\text { kemampuan } \\
\text { pada tiap tahap } \\
\text { pembelajaran } \\
\text { (dalam menit) }\end{array}$ & $\begin{array}{l}\text { Jenis, bentuk dan } \\
\text { instrumen } \\
\text { evaluasi yang } \\
\text { akan digunakan } \\
\text { atau dilakukan } \\
\text { oleh dosen }\end{array}$ & $\begin{array}{l}\text { Kriteria } \\
\text { kompetensi } \\
\text { yang harus } \\
\text { dimiliki } \\
\text { mahasiswa, } \\
\text { indikator } \\
\text { jabaran dari } \\
\text { setiap } \\
\text { kompetensi } \\
\text { dan bobot } \\
\text { penilaian }\end{array}$ & $\begin{array}{l}\text { Referensi yang } \\
\text { digunakan } \\
\text { sebagai } \\
\text { tambahan dar } \\
\text { bahan ajar. } \\
\text { (website, video } \\
\text { youtube, artikel, } \\
\text { tugas akhir } \\
\text { mahasiswa, } \\
\text { diktat, buku teks, } \\
\text { modul, dll) }\end{array}$ \\
\hline
\end{tabular}

Gambar 1. Bentuk dari RPS

\section{B. Pelaksanaan Pembelajaran dengan Penerapan Model PjBL}

Setelah melakukan penelitian tentang penerapan model PjBL pada mata kuliah praktek las II pada program studi Teknik Mesin AKNTD, maka diperoleh deskripsi dari kegiatan pembelajaran yang telah dilakukan. Kegiatan pembelajaran yang dilakukan merupkan realisasi dari rencana pembelajaran yang telah dilakukan dengan menggunakan panduan kegiatan pembelajaran yaitu RPS. Desikripsi dari pelaksanaan kegiatan pembelajaran pada mata kuliah Praktek Las II dengan penerapan model $\mathrm{PjBl}$ dijabarkan sebagai berikut:

\section{Perumusan Capaian Pembelajaran}

Kegitan pembelajaran perumusan capaian pembelajaran dilaksanakan pada pertemuan pertama dengan alokasi waktu satu pertemuan (enam jam pembelajaran). Dosen juga menjelaskan RPS, keterkaitan kegiatan pembelajaran dengan dunia kerja, dan menjelaskan potensi daerah, tantangan atau masalah yang berkembang dimasyarakat yang dapat dikembangkan atau dipecahkan melalui pembelajaran yang akan dilaksanakan. Kegiatan perumusan capaian pembelajaran ini bermaksut agar mahasiswa memahami dengan capaian pembelajaran yang akan diperolehnya setelah mengikuti mata kuliah ini, begitu juga dengan gambaran kegiatan perkuliahan yang akan dilaksanakan selama satu semester dan tugas proyek yang akan dilaksanakan. Hal ini bertujuan untuk memotivasi mahasiswa. 
Kegiatan pembelajaran dilaksanakan dengan ceramah dari Dosen dan dilanjutkan dengan diskusi kelas.

Untuk mengevaluasi ketercapaian dari kegiatan pembelajaran pada tahap satu ini dapat dilakukan dengan memberikan tugas mandiri kepada mahasiswa yang terdiri dari beberapa tugas pertanyaan, seperti: 1) Tuliskan dan jabarkan garisgaris besar rencana pembelajaran yang akan dilaksanakan selama satu semester, 2) apa keterkaitan dari pembelajaran yang dipelajari dengan kompetensi yang dibutuhkan oleh dunia industri, dan 3) tuliskan beberapa potensi daerah, tantangan atau permasalahan yang dapat dikembangkan atau dipecahkan melalui tugas proyek yang akan dikerjakan.

\section{Penguasaan Bahan Kajian}

Kegiatan pembelajaran penguasaan bahan kajian dilaksanakan pada pertemuan tata muka ke-2 dan ke3 ( 2 pertemuan $\times 6$ jam pelajajaran $\times 50$ menit $=600$ menit tatap muka). Penentuan alokasi waktu ini didsarkan kepada mahasiswa sebelumnya sudah mempelajari materi tentang pengelasan pada mata kuliah Teknologi Mekanik dan Praktek Las I, sehingga pada kegiatan pembelajaran Praktek Las II, hanya untuk menggulang atau penyegaran materi yang telah dipahami oleh Mahasiswa. Bahan kajian yang dipelajari oleh mahasiswa terdiri dari materi pengelasan SMAW, OAW, TIG dan MIG.

Metode pembelajaran yang dilaksanakan pada kegiatan pembelajaran ini adalah self-learning, dimana Mahasiswa mempelajari materi secara mandiri melalui modul. Agar Mahasiswa benarbenar belajar secara mandiri dan sungguh-sungguh, maka stategi yang dilakukan adalah Mahasiswa membuat ringkasan dari materi yang dipelajari, mempresentasikan didepan kelas dan diskusi kelas. Kegiatan presentasi dan diskusi kelas dapat menjadi evaluasi bagi Dosen untuk mengetahui ketercapain kemampuan akhir yang diharapkan dan kegiatan evaluasi dapat ditambah dengan menginstruksikan Mahasiswa untuk mengerjakan soal-soal tes yang ada pada modul.

\section{Latihan Keterampilan Pengelasan}

Kegiatan pembelajaran latihan keterampilan dilaksanakan pada pertemuan ke-4 sampai dengan pertemuan ke-7 ( 4 pertemuan $\mathrm{x} 6$ jam pelajajaran $\mathrm{x}$ 50 menit $=1200$ menit tatap muka). Latihan kerampilan pengelasan ini bertujuan untuk memberikan pelatihan kepada Mahasiswa tentang teknik pengelasan SMAW, OAW, MIG dan TIG yang sesuai dengan standar operasional kerja (SOP), sehingga ketika pelaksanaan tugas proyek Mahasiswa sudah memiliki dasar keterampilan pengelasan. Kegiatan pembelajaran pada latihan ini dilaksanakan dengan metode pengajaran lansung, dimana langkah-langkahnya terdiri dari: 1) Dosen menjelaskan tentang tujuan latihan keterampilan, 2) mendemonstrasikan teknik pengelasan tanpa menjelaskan tahap-tahap yang dilakukan (mendemonstrasikan seperti seorang profesional), 3) mendemonstrasikan sambil menjelaskan tahap-tahap pengerjaan sesuai SOP, 4) Dosen menginstruksikan salah seorang Mahasiswa untuk mendemonstrasikan, membimbing mahasiswa tersebut dan memberikan pertanyaan rasional terhadap apa yang dilakukan oleh Mahasiswa tersebut (feedback), dan 5) Mahasiswa diinstruksikan untuk latihan secara mandiri dengan pengawasan dan pembimbingan oleh Dosen.

Sehubungan dengan jumlah mesin dan peralatan las yang tidak mencukupi untuk mahasiswa apabila yang pembelajaran difokuskan pada satu jenis pengelasan, maka strateginya mahasiswa dibagi menjadi empat kelompok sesuai dengan jumlah jenis pengelasan yang dipelajari ada satu pertemuan dan pada pertemuan berikutnya kelompok mahasiswa bergantian untuk latihan pada jenis pengelasan lainya. Dalam hal ini berarti Mahasiswa harus menyelesaikan job/benda kerja latihan dan kompetensi pengelasan untuk satu jenis pengelasan dalam satu pertemuan, dan mahasiswa untuk dapat berpindah kepada latihan pada jenis pengelasan lainya, mereka harus tuntas dalam artian hasil pengelasan mereka harus sesuai dengan kriteria. Hal ini juga mendorong mahasiswa untuk serius dan konsentrasi penuh pada kegiatan pembelajaran latihan keterampilan pengelasan.

\section{Rancangan Tema Proyek}

Kegiatan pembelajaran rancangan tema proyek dilaksanakan pada pertemuan ke-8 dengan alokasi waktu satu pertemuan. Pada kegiatan pembelajaran ini Dosen dan mahasiswa berdiskusi tentang tema dari tugas proyek mahasiswa. Landasan pemilihan tema tugas proyek adalah potensi daerah dan masalah yang terjadi tentang kenapa potensi daerah belum dikembangkan. Dari hasil diskusi antara Dosen dan Mahasiswa tentang potensi daerah disekitaran Akademi Komunitas Negeri Tanah Datar adalah pada bidang pertanian, masalahnya saat ini masih banyak petani yang menggunakan alat pertanian konvensional. Kesepakatan bersama antara Dosen dan Mahasiswa adalah tugas proyek semua kelompok membuat alat-alat pertanian sederhana yang dapat membantu masyarakat petani dalam usahanya. 
5. Pembuatan Proposal Proyek

Kegiatan pembelajaran pembuatan usulan tugas proyek dilaksanakan pada pertemuan ke-9 dan ke-10 ( 2 pertemuan $\times 6$ jam pelajajaran $\times 50$ menit $=600$ menit tatap muka). Kemampuan akhir yang diharapkan dari kegiatan pembelajaran ini adalah mahasiswa mampu menyusun proposal proyek, yang terdiri dari pembuatan latar belakang, indetifikasi masalah, solusi yang ditawarkan, deskripsi alat, gambar kerja dan estimasi produksi dari alat yang akan dibuat. Kegiatan pembelajaran dilaksanakan dengan proses pembimbingan oleh dosen pada masing-masing kelompok tugas proyek mahasiswa.

\section{Pengerjaan Tugas Proyek}

Kegiatan pembelajaran tugas proyek dilaksanakan pada pertemuan ke-11 sampai pertemuan ke-17 (7 pertemuan x 6 jam pelajajaran $\mathrm{x}$ 50 menit $=2100$ menit tatap muka). Kemampuan akhir yang diharapkan dari kegiatan pembelajaran ini adalah 1) mahasiswa memiliki pengalaman nyata dalam membuat sebuah produk nyata yang diangkat dari potensi daerah atau masalah dari dunia nyata, 2) memantapkan keterampilan teknik pengelasan mahasiswa melalui tugas proyek nyata, dan 3) melalui pengalaman belajar dari tugas proyek mahasiswa memiliki kompetensi soft skills, seperti: kerja sama tim, komunikasi, memecahkan masalah, manajemen kerja, kreatifitas, dan keterampilan mengambil keputusan. Peranan dosen dalam kegiatan pengerjaan tugas proyek ini adalah sebagai motivator, mentor, evaluator dan fasilitator. Teknik penilaian yang dapat digunakan pada tahap ini adalah teknik penilaian autentik dengan rubric penilaian pengerjaan tugas proyek.

\section{Presentasi Laporan Tugas Proyek}

Kegiatan pembelajaran yang terakhir adalah presentasi laporan tugas proyek yang dilaksanakan pada pertemuan ke-18. Kemampuan akhir yang diharapkan dari kegiatan pembelajaran ini adalah Mahasiswa mampu mengkomunikasikan dengan mempresentasikan laporan tugas proyek dalam bentuk seminar kelas. Hasil produk mahasiswa dapa dilihat pada tabel 1 .

Tabel 1. Hasil Tugas Proyek Mahasiswa

\begin{tabular}{|l|l|}
\hline Tugas Proyek & \multicolumn{2}{|c|}{ Deskripsi Produk } \\
\hline Alat pengembur tanah \\
inovatif pengganti sekop \\
atau cangkul, dengan \\
keunggulan tidak \\
memerlukan tenaga yang \\
besar untuk \\
menggunakannya karena \\
memanfaatkan berat \\
badan dan hasil tanah
\end{tabular}

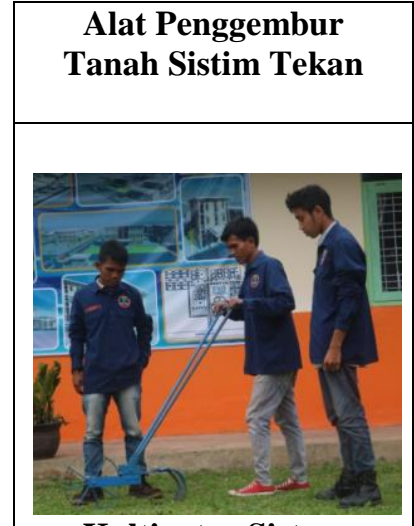

Kultivator Sistem Dorong Mata cakar

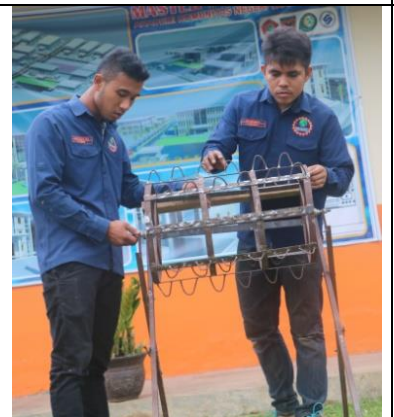

Thresher Lipat Dengan Pedal

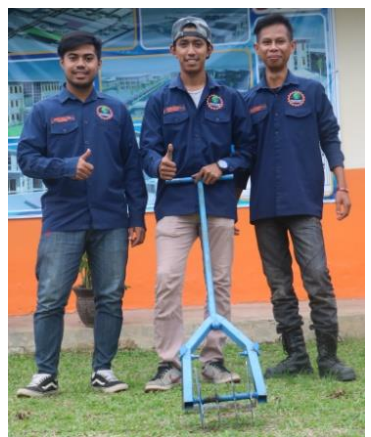

Kultivator Sistem Dorong Mata Bintang

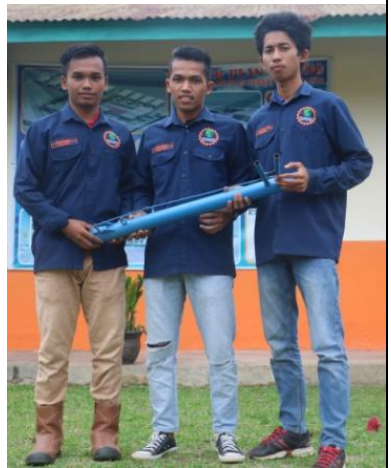

Tranplanter Benih yang digemburkan lebih besar lebarnya dari sekop atau cangkul.

Kultivator sistem dorong mata cakar pengganti garpu manual dan cangkul untuk mengolah tanah dan membunuh gulma dan rumputrumputan disekeliling tanaman muda. Keunggulan dari alat ini adalah mudah pengoperasiannya, tidak memerlukan tenaga yang besar dan cepat kerjanya. Thresher lipat dengan pedal merupakan alat perontok padi manual menggunakan pedal sebagai mekanik untuk menggerakan silinder perontok. Keunggulan dari alat ini adalah cukup dioperasikan oleh satu orang dan bisa dilipat sehingga mudah untuk dibawa.

Kultivator sistem dorong mata bintang ini adalah alat untuk penggembur tanah, pembunuh gulma dan rumput-rumputan disekeliling tanaman muda. Keunggulan dari alat ini adalah pada roda yang berbentuk bundar dengan pinggirannya bergerigi yang mempunyai 3 fungsi yaitu sebagai pengembur tanah, pembunuh gulma atau rumput dan sebagai penghasil gerakan dengan cara bergulir.

Tranplanter bibit yaitu alat untuk menanam benih palawija seperti benih cabe, benih tomat dan benih sayuran. Penggunaan alat ini sangat mudah yaitu dengan cara menancapkan ke tanah dan memasukan benih kedalam pipa saluran lalu menekan tuas, sehingga akar benih masuk kedalam tanah. 


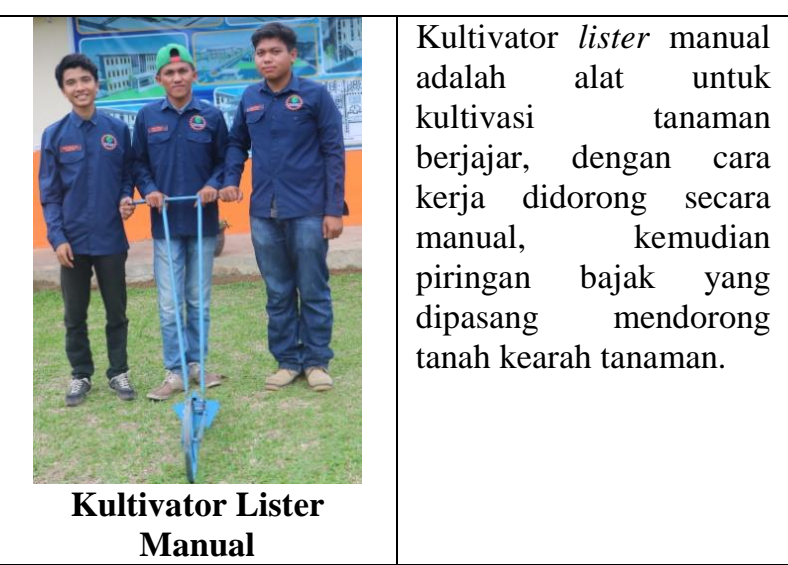

\section{KeSimPUlan}

Melalui penerapan model PjBL pada kegiatan pembelajaran mahasiswa mendapatkan kesempatan untuk membuat produk nyata yang dapat mengembangkan potensi daerah atau memecahkan masalah yang berkembang disekitaran Akademi Komunitas. Kegiatan pembelajaran yang menggali potensi, tantangan atau masalah pada daerah dilaksanakan pada kegiatan pembelajaran rencangan tema proyek, selanjutnya mahasiswa merumuskan solusi untuk memecahkan masalah atau mengembangkan potensi daerah tersebut dan baru mahasiswa membuat produk sesuai dengan tema tugas proyek. Pada pembelajaran Praktek Las mahasiswa membuat tugas proyek berupa alat-alat pertanian untuk mengembang pertanian dan membantu petani yang ada didaerah sekitaran Akademi Komunitas Negeri Tanah Datar. Berdasarkan hal ini maka dapat disimpulkan untuk mewujudkan tujuan Akademi Komunitas dalam mengembangkan potensi, menjawab tantangan atau memecahkan masalah daerah dapat terlaksana melalui pembelajaran dengan penerapan model PjBL.

\section{DAfTAR Pustaka}

[1] Presiden Republik Indonesia. Undang-Undang Republik Indonesia Nomor 12 Tahun 2012 Tentang Pendidikan Tinggi. Jakarta: Menteri Hukum dan Hak Asasi Manusia Republik Indonesia. 2012.

[2] Direktorat Pembelajaran dan Kemahasiswaan. Panduan Kurikulum Akademi Komunitas. Jakarta: Direktorat Jendral Pendidikan Tinggi Kementrian Pendidikan dan Kebudayaan. 2013.

[3] Milentijevic, I., Ciric, V. \& Vojinovic, O. Version control in project-based learning. Computers and Education-1331-1338. 2008.

[4] Wena, M. Strategi Pembelajaran Inovatif Kontemporer. Jakarta: PT. Bumi Askara. 2012.
[5] Jalinus, N., Arwizet, K, Nabawi, R. A. and Ambiyar. Improve Learning Outcomes of Students Through Implementation of The Collaborative Project-Based Learning Model in Thermodynamics. Proceeding the 1st International Conference on Education Innovation. Vol. 1. No. 1. 2017.

[6] N. Jalinus and R. A. Nabawi, "Implementation of the PjBL Model to Enhance Problem Solving Skill and Skill Competency of Community College Student," J. Pendidik. Vokasi, vol. 7, no. 3, pp. 304-311, 2017.

[7] Nabawi, R. A. Penerapan Model Project Based Learning untuk Meningkatkan Kemampuan Pemecahan Masalah dan Kompetensi Keahlian Praktek Las Mahasiswa Program Studi Teknik Mesin Akademi Komunitas Negeri Tanah Datar. Master Thesis. Padang: Universitas Negeri Padang. 2017.

[8] Direktorat Jenderal Pendidikan Tinggi. Buku Kurikulum Pendidikan Tinggi. Jakarta : Kementrian Pendidikan dan Kebudayaan. 2014.

[9] Markham, Thom. Project Based learning: Design and Coaching Guide. Canada: Wilsted \& Taylor Publishing Services. 2012.

[10] Patton, Alec. Work that Matters: The teacher's guide to Project Based Learning. England: Paul Hamlyn Foundation. 2012.

[11] Rais, Muh. Project Based Learning: Inovasi pembelajaran yang berorientasi soft skills. Makalah Disajikan dalam Seminar Pendidikan Teknologi dan Kejuruan Fakultas Teknik Universitas Negeri Surabaya, Surabaya, 11 Desember 2010.

[12] Jalinus, N., Nabawi, R. A. and Mardin, A. The Seven Steps of Project Based Learning Model To Enhance Productive Competences of Vocational Students. $1^{\text {st }}$ International Conference on Technology and Vocational Teacher (ICTVT 2017). Atlantis Press. Advances in Social Science, Education and Humanities research, Volume 102. 2017: 251-256.

\section{Biodata Penulis}

Rahmat Azis Nabawi menerima gelar Sarjana dan Masternya dari Jurusan Teknik Mesin Fakultas Teknik Universitas Negeri Padang. Minat penelitiannya adalah di bidang Pendidikan Teknologi Kejuruan. Sejak saat mulai bekerja sebagai seorang Dosen di Universitas Negeri Padang, telah melakukan banyak penelitian dan pengabdian masyarakat dalam teknologi kurikulum pendidikan teknologi kejuruan, teknologi terapan dan pengembangan kapal. 